\title{
AMERIŠKI CIVILNO-VOJAŠKI ODNOSI, VOJAK IN DRŽAVA V NOVI DOBI
}

Petdeset let po objavi Huntingtonove teorije o civilno-vojaških odnosih sta Suzanne C. Nielsen in Don M. Snider, profesorja z ameriške vojaške akademije West Point, zbrala skupino priznanih strokovnjakov političnih in družbenih ved ter zgodovine s temeljnim namenom: analizirati značilnosti civilno-vojaških odnosov v ZDA ter ugotoviti uporabnost Huntingtonove teorije za proučevanje sodobnih civilno-vojaških odnosov. Z uporabo njegove teorije so proučevali razvoj in stanje ameriških civilno-vojaških odnosov, predvsem v kontekstu dogodkov po 11. 9. 2001 in vojne v Iraku. Vsebina proučevanja so bili odnosi med civilnimi in vojaškimi voditelji, proces sprejemanja odločitev na strateški ravni in vloga vojaškega nasveta, sodoben odnos med družbenim in funkcionalnim imperativom vojske, podrejenost vojske civilnim avtoritetam, značilnosti vojaške profesije in vojaške etike ter odnos med zakonodajno in izvršno vejo oblasti. Knjiga ${ }^{1}$ je nekakšen učbenik, kako se metodološko, analitično in interdisciplinarno lotiti proučevanja, med drugim daje tudi kratek presek razvoja družboslovnih ved.

V knjigi sedemnajst avtorjev z različnim pristopom posreduje poglede na civilno-vojaške odnose v ZDA in ocenjuje vrednost Huntingtonove teorije v tem stoletju. Skupna ugotovitev je, da je tradicija dobrih civilno-vojaških odnosov prekinjena in da se pojavlja potreba po njihovem »popravilu«, predvsem procesa strateškega odločanja in definiranja obrambne politike, odnosov med civilnimi in vojaškimi voditelji ter vloge in kakovosti vojaškega nasveta. Betz se na primer sprašuje o meji med civilno in vojaško sfero in trdi, da objektivni nadzor ni absolutno dober, kot tudi subjektivni ni izključno škodljiv. Podobno Gibson ugotavlja pomanjkljivosti popolne ločenosti civilne in vojaške sfere ter izpostavlja potrebo po spremembi zakonodaje in vedenjskih norm. Kohn se pridružuje Gibsonovem razmišljanju o

Uredila Suzanne C. Nielsen in Don M. Snider, izdal The Johns Hopkins University Press, Baltimore, 2009, 409 strani. 
civilnih in vojaških normah vedenja in se sprašuje o načinih povrnitve zaupanja med civilnimi in vojaškimi voditelji.

Moten s proučevanjem odnosa med obrambnim sekretarjem Rumsfeldom in načelnikom kopenske vojske Shinsekijem analizira razloge za konflikte med civilnimi in vojaškimi voditelji ter kako se jim izogniti. Brooksova ga dopolnjuje $\mathrm{z}$ analizo oblik političnega udejstvovanja generalov in ugotavlja, da posledice niso vedno samo negativne. Burk pa se osredotoča na vprašanje o mejah vojaške poslušnosti in moralnih dilemah izpolnjevanja ukazov.

Feaver in Seeler prek razvoja družbenih ved in analize metodološkega aparata za proučevanje civilno-vojaških odnosov potrjujeta relevantnost Huntingtonove teorije za prihodnje študije. Ugotovitvam se pridružuje Desch, ki se je osredotočil na proučevanje civilno-vojaških odnosov v kontekstu ameriške liberalne tradicije in ugotovil, da je kljub kritikam teorija objektivnega nadzora še vedno najboljši okvir reševanja trenj med liberalno kulturo in konservativnim etosom vojaške profesije. Driver pa raziskuje povezavo med ideologijo in vojaškim profesionalizmom in dokazuje, da ni mogoče trditi, da je vojska prežeta s konservativnostjo in skupno ideologijo, ki izhajata iz profesionalizma, in povzema, da skupne vrednote izhajajo iz družbenih.

Schadlow in Lacquement izpostavljata neprimernost teorije objektivnega nadzora in značilnosti vojske kot »upravljavca nasilja« v kontekstu stabilizacijskih operacij ter potrebe po njenem prilagajanju. Segal in De Angelis na podlagi analize razvoja vojaške profesije ugotavljata šibkosti Huntingtonove teorije v sodobni vojaški organizaciji, v kateri ima podčastniški zbor večjo vlogo kot v njegovem času, ter da govorimo o pojavu civilistov v vojaški organizaciji, ki so tudi »upravljavci nasilja«. O potrebi po prilagajanju vojaške organizacije govori tudi Murray, ki poudarja pomen vojaškega izobraževanja in potreb po intelektualnem razvoju vojaških voditeljev ter s tem povezanih potreb prilagajanja vojaškega izobraževanja sodobnim zahtevam.

Spoznanja in sporočila avtorjev so lahko v pomoč vsem, ki proučujejo civilno-vojaške odnose, civilni nadzor in vlogo vojske v družbi. Čeprav so bili predmet proučevanja ameriški civilno-vojaški odnosi, so ugotovitve univerzalne in govorijo o mogočih odklonih v civilno-vojaških odnosih razvitih demokracij. Knjiga prinaša sporočila, kaj jih povzroča, kako jih prepoznavati in kakšne so posledice. Posreduje tudi napotke za uveljavljanje vojaških in civilnih norm vedenja za dvig ravni civilno-vojaških odnosov v praksi.

Posebej koristne so ugotovitve o današnji primernosti in vrednosti Huntingtonove teorije. Čeprav je bila v zgodovini večkrat kritizirana in tudi v tej knjigi avtorji odkrivajo njene šibkosti, je še vedno izredno dober in uporaben metodološki okvir ter izhodiščna točka za proučevanje sodobnih civilno-vojaških odnosov. Z analizo različnih primerov v praksi avtorji izpostavljajo njene pomanjkljivosti in dajejo napotke, kako se jim izogniti. Opozarjajo predvsem na zmotno razumevanje popolnega ločevanja vojaške in civilne sfere. Skupna ugotovitev je, da so v 21. 
stoletju pomen ravnotežja med družbenim in funkcionalnim imperativom, ki oblikujeta vojsko, odnos med civilnim nadzorom in učinkovitostjo vojske ter značilnosti vojaške profesije in vojaške etike še vedno zelo aktualne in uporabne vsebine Huntingtonove teorije. 